\title{
Possible upregulation of hypothalamic 5-hydroxytryptamine receptors in patients with postviral fatigue syndrome
}

\author{
A M O Bakheit, P O Behan, T G Dinan, C E Gray, V O'Keane
}

\begin{abstract}
Objective-To study the dynamic function of hypothalamic 5-hydroxytryptamine receptors in patients with postviral fatigue syndrome.

Design-Prospective comparison of patients with postviral fatigue syndrome with two control groups.

Setting-Department of neurology, University of Glasgow, Southern General Hospital; department of psychiatry, St James's Hospital, Dublin.

Subjects -15 patients with postviral fatigue syndrome, 13 age and sex matched healthy subjects, and 13 patients with primary depression.

Main outcome measures-Serum prolactin concentrations before and one, two, and three hours after administration of buspirone.

Results-Because of the effects of sex hormones on prolactin secretion data for men and women were analysed separately. There was no significant difference in baseline prolactin concentrations between patients with postviral fatigue syndrome and healthy subjects or those with primary depression. However, the percentage difference between peak and baseline values was significantly higher in patients with postviral fatigue syndrome than the control groups (one way analysis of variance: women, $p=0.003$; men, $p=0.004$ ).

Conclusions - The results suggest upregulation of hypothalamic 5-hydroxytryptamine receptors in patients with postviral fatigue syndrome but not in those with primary depression. The buspirone challenge test may therefore be useful in distinguishing these two conditions. Larger studies are required to explore the potential value of drugs acting on central 5-hydroxytryptamine receptors in the treatment of patients with the postviral fatigue syndrome.
\end{abstract}

\section{Introduction}

In recent years postviral fatigue syndrome has become a recognised clinical entity. The illness follows an acute viral infection and may occur sporadically or in epidemics. ${ }^{12}$ The core symptoms of the disease are excessive fatigue and lethargy, which last six months or more. The fatigue is usually accompanied by myalgia, which is precipitated or aggravated by exercise. In the early stages of the disease the majority of patients complain of symptoms suggestive of hypothalamic dysfunction. These include changes in appetite and body weight, fluid retention, irregular menstruation, excessive sweating, hot flushes, reversed sleep pattern, poor memory and concentration, and depression. ${ }^{3}$ About one third of patients develop palpitations or unsteadiness, or both. ${ }^{4}$ The disease is characterised by a protracted and fluctuating course with periods of relapses and remissions.

The multiple symptomatology and the paucity of abnormal findings on physical examination have led to the view that postviral fatigue syndrome may be a somatisation disorder occurring in patients with predisposition to psychiatric disease. ${ }^{5}$ However, in the past few years evidence which shows the organic nature of this condition has accumulated. For example, using nucleic acid hybridisation techniques Archard et al have detected the presence of enteroviral RNA sequence in $20 \%$ of patients with postviral fatigue syndrome. ${ }^{6}$ More recently Gow et al have examined muscle biopsy samples from 60 patients with postviral fatigue syndrome with a polymerase chain reaction technique and found enteroviral RNA viral sequences in $53 \%$ of patients compared with $16 \%$ of controls. Muscle damage consisting of type 2 fibre atrophy has been reported in these patients. ${ }^{8}$ Furthermore, mitochondrial abnormalities have been found in most patients with postviral fatigue syndrome.9 These changes consist of pleomorphism of muscle mitochondria, proliferation of cristae, and increase in lipid and glycogen content. Single fibre electromyographic studies confirmed muscle membrane abnormalities, ${ }^{10}$ and early intracellular acidosis out of proportion to the associated rise in high energy phosphate values during exercise was found in these patients by magnetic resonance imaging. ${ }^{11}$

A major source of 5-hydroxytryptamine in brain outside the raphe complex is the hypothalamus. ${ }^{12} 5$ Hydroxytryptamine pathways have been implicated in the control of various hypothalamic functions, including temperature regulation, sleep, appetite, mood, and memory. ${ }^{13}$ Stimulation of hypothalamic 5-hydroxytryptamine pathways promotes prolactin release in humans, an effect which is blocked by the 5hydroxytryptamine antagonists methysergide ${ }^{14}$ and metergoline. ${ }^{15}$ Administration of drugs which selectively affect 5-hydroxytryptamine neurones and serial measurements of serum prolactin concentrations during these neuroendocrine challenge tests therefore allows the study of the functional activity of hypothalamic 5-hydroxytryptamine receptors. ${ }^{16}$ Recently, buspirone, an anxiolytic with 5-hydroxytryptamine $1 \mathrm{~A}$ receptor agonist properties, has been shown to stimulate prolactin release by acting on hypothalamic 5-hydroxytryptamine receptors. ${ }^{17-19}$ In this study we used the buspirone challenge test to determine the functional activity of hypothalamic 5-hydroxytryptamine receptors in patients with postviral fatigue syndrome.

\section{Subjects and methods}

Fifteen consecutive patients admitted for diagnostic work up of postviral fatigue syndrome participated. There were nine men and six women with a mean age at onset of the disease of 38.8 and 33.3 years respectively. The onset of symptoms was preceded by a definite or probable viral infection in all patients. In addition to chronic fatigue, patients had three or more of the following symptoms: myalgia, reversed sleep pattern, depression, excessive sweating, constipation alternating with diarrhoea, palpitations, and unsteadiness. None of the patients had a past or family history of psychiatric illness and all had a good previous work record. All patients had a needle muscle biopsy sample taken from the vastus lateralis of quadriceps femoris.

Controls consisted of age and sex matched healthy volunteers and patients with primary depression. The healthy volunteers were recruited from hospital staff,
Institute of Neurological

Hospital, Glasgow G51 4TF. 
and patients with primary depressive illness were randomly selected from an outpatient psychiatric clinic population. There were seven men and six women in each group. Depressive illness was diagnosed according to criteria of the Diagnostic and Statistical Manual of Mental Disorders, Third Edition, Revised. ${ }^{20}$ The mean age of patients with depressive illness was 35.0 years for men and $31 \cdot 1$ years for women, and all patients had a Hamilton depression score of more than $20 .{ }^{21}$ The mean age of healthy men and women was 36.0 and 30.6 years respectively. None of the patients or controls was on any medication for at least six weeks before the study. All women who were menstruating normally were studied during the luteal phase.

Patients and controls were fasted overnight. At 830 am a cannula was inserted into the antecubital vein and a blood sample for baseline prolactin estimation taken 15 minutes later. Subjects were then given $60 \mathrm{mg}$ buspirone orally at $9 \mathrm{am}$. Further blood samples were collected hourly for three hours. Prolactin concentrations were measured blind to diagnosis by immunometric assay. Assays were standardised against National Institute for Biological Standards and Control $3 \mathrm{~d}$ international standard $84 / 500$, and the within and between batch coefficients of variation were $3 \%$ and $6 \%$ respectively over the concentration range 200 $3000 \mathrm{mU} / \mathrm{l}$.

The response to buspirone was determined by subtracting baseline from peak prolactin concentrations and the latter value expressed as a percentage of baseline. Data for men and women were analysed separately (see below) bý one way analysis of variance.

\section{Results}

All patients and controls completed the study satisfactorily. The buspirone caused excessive fatigue, lightheadedness, and nausea in patients but not in controls. Electron microscopy of muscle biopsy samples showed mitochondrial changes similar to those previously described in patients with postviral fatigue syndrome ${ }^{9}$ in all patients, and RNA enteroviral sequences were detected with the polymerase chain reaction in six.

The mean prolactin values before and after oral administration of $60 \mathrm{mg}$ buspirone are given in table $\mathrm{I}$. Peak prolactin rise occurred at one hour in patients with postviral fatigue syndrome and women in the control groups and at two hours in healthy and depressive men. There was no significant difference in baseline prolactin values between patients with postviral fatigue syndrome, healthy individuals, nd patients with primary depressive illness. Similarly,

TABLE I-Mean (SD) prolactin concentrations ( $m U / l)$ before and mean ( $95 \%$ confidence intervals) after administration of $60 \mathrm{mg}$ buspirone to patients with postviral fatigue syndrome, patients with primary depressive illness, and healthy subjects

\begin{tabular}{|c|c|c|c|}
\hline & $\begin{array}{l}\text { Patients with postviral } \\
\text { fatigue syndrome }\end{array}$ & $\begin{array}{l}\text { Patients with primary } \\
\text { depressive illness }\end{array}$ & Healthy subjects \\
\hline $\begin{array}{l}\text { Baseline } \\
1 \text { Hour } \\
2 \text { Hours } \\
3 \text { Hours }\end{array}$ & $\begin{array}{l}178(75) \\
882(548 \text { to } 1215) \\
490(305 \text { to } 674) \\
318(192 \text { to } 444)\end{array}$ & $\begin{array}{l}179(48) \\
318(156 \text { to } 479) \\
373(262 \text { to } 484) \\
262(138 \text { to } 385)\end{array}$ & $\begin{array}{l}163(49) \\
392(290 \text { to } 494) \\
401(294 \text { to } 508) \\
317(195 \text { to } 439)\end{array}$ \\
\hline $\begin{array}{l}\text { Percentage difference } \\
\text { between peak and } \\
\text { baseline }\end{array}$ & 426 (230 to 622$)$ & 123 (52 to 195$)$ & 163 (79 to 246$)$ \\
\hline $\begin{array}{l}\text { Baseline } \\
1 \text { Hour } \\
2 \text { Hours } \\
3 \text { Hours }\end{array}$ & $\begin{array}{l}326(166) \\
2678(1187 \text { to } 4168) \\
1367(344 \text { to } 2389) \\
659(324 \text { to } 993)\end{array}$ & $\begin{array}{l}227(75) \\
809(379 \text { to } 1238) \\
742(338 \text { to } 1145) \\
511(313 \text { to } 708)\end{array}$ & $\begin{array}{l}188(28) \\
725(265 \text { to } 1185) \\
681(308 \text { to } 1053) \\
562(271 \text { to } 852)\end{array}$ \\
\hline $\begin{array}{l}\text { Percentage difference } \\
\text { between peak and } \\
\text { baseline }\end{array}$ & 738 (432 to 1043$)$ & 260 (122 to 398$)$ & 309 (215 to 503$)$ \\
\hline
\end{tabular}

comparison between patients with postviral fatigue syndrome (PVFS) and each of the two control groups did not reveal a significant difference (PVFS $v$ healthy subjects: $\mathrm{p}=\mathbf{0 . 6}$ for men, $\mathrm{p}=\mathbf{0} .09$ for women; PVFS $v$ depressive subjects: $p=0.9$ for men, $p=0.2$ for women). However, the percentage difference between peak and baseline prolactin concentrations was significantly higher in patients with postviral fatigue syndrome than in healthy controls and patients with primary depression (table II). There was also a

TABLE II-One way analysis of variance of baseline prolactin concentrations and percentage difference between peak and baseline concentrations in patients with postviral fatigue syndrome, healthy control subjects, and patients with primary depression

\begin{tabular}{|c|c|c|c|c|}
\hline & $\begin{array}{l}\text { Sum of } \\
\text { squares }\end{array}$ & $\begin{array}{l}\text { Mean of } \\
\text { squares }\end{array}$ & $F$ test value & p Value \\
\hline \multicolumn{5}{|c|}{ Baseline } \\
\hline Men & 1240 & 620 & $0 \cdot 17$ & $0 \cdot 8$ \\
\hline Women & 61008 & 30504 & $2 \cdot 40$ & $0 \cdot 1$ \\
\hline \multicolumn{5}{|c|}{ Percentage difference between peak and baseline } \\
\hline $\begin{array}{l}\text { Men } \\
\text { Women }\end{array}$ & 444079 & 222040 & $7 \cdot 29$ & 0.004 \\
\hline Women & 828671 & 414336 & $9 \cdot 07$ & 0.003 \\
\hline
\end{tabular}

significant difference when patients with postviral fatigue syndrome were compared with each control group separately (PVFS $v$ healthy subjects: $p=0.02$ for men, $p=0.01$ for women; PVFS $v$ depressive subjects: $p=0.01$ for men, $p=0.004$ for women).

\section{Discussion}

We selected patients with postviral fatigue syndrome for this study according to strict criteria which were based on extensive observations. ${ }^{32}$ Furthermore, most of these patients had objective evidence of muscle damage as shown by mitochondrial changes and the persistence of enteroviral RNA sequences in muscle. Female sex hormone fluctuations influence prolactin concentrations. ${ }^{16}$ Hence female patients (who were menstruating regularly) were studied in the luteal phase of the menstrual cycle and data for male and female patients were analysed separately.

The results of this study show an increased prolactin response to buspirone challenge in patients with postviral fatigue syndrome compared with healthy individuals and also patients with primary depressive illness. Prolactin release in response to buspirone administration seems to be mediated by 5 -hydroxytryptamine receptors since it can be blocked by specific 5-hydroxytryptamine antagonists-for example, methysergide ${ }^{14}$ and metergoline. ${ }^{15}$ Our findings therefore suggest an increased sensitivity of central 5hydroxytryptamine receptors in postviral fatigue syndrome and may lead to improved understanding of the pathogenesis of this disorder and help in the rational planning of therapeutic trials.

Patients with primary depressive illness often present with neuroendocrine symptoms indistinguishable from those of postviral fatigue syndrome. ${ }^{23}$ Because of the significantly lower prolactin response to buspirone in patients with primary depression compared with the response in patients with postviral fatigue syndrome the buspirone challenge test may be useful in the differential diagnosis of these conditions. We are currently studying a larger group of patients to extend these observations.

This work was supported by a grant from the Barclay Trust.

1 Acheson ED. The clinical syndrome variously called benign myalgic encephalomyelitis, Iceland disease and epidemic neuromyasthenia. Am f Med 1959;26:569-95.

2 Fagan KG, Behan PO, Bell EJ. Myalgic encephalomyelitis-report of an epidemic. $7 R$ Coll Gen Pract 1983;33:335-7. 
3 Behan P(), Bakheit AMO. Clinical spectrum of postviral fatigue syndrome. Br Med Bull 1991:47:793-808.

4 Behan PO, Behan WMH. Postriral fatigue syndrome CRC Cril Rez Neurobiol 1988:4:157-78.

5 Cluff E. Medical aspects of delayed convalescence. Rev Infect Dis 1991;13 suppl 1):138-40.

6 Archard LC, Bowles NE, Behan PO, Bell EJ, Doyle D. Postriral fatigue syndrome: persistence of enterovirus RNA in muscle and elevated creatine kinase. f R Soc Med 1988;81:326-9.

7 Gow JW, Behan WMH. Clements GB, Woodall C, Miller J, More IAR, et al. Enteroviral sequences detected by polvmerase chain reaction in muscle biopsies of patients with the postriral fatigue sindrome. B.MY 1991:302: $692-6$

8 Behan PO, Behan $W M H$, Bell EJ. The postviral fatigue syndrome-an analysis of the findings in 50 cases. 7 Infec 1985:10:211-22.

Gow JT, Behan WMH. Amplification and identification of enterovirat

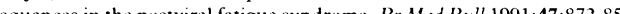

Jamal GA, Hansen S. Post-viral fatigue syndrome: evidence for underlying organic disturbance in the muscle fibre. E. Nur Neurol 1989;29:272-6.

11 Arnold DL, Bore PJ, Radda GK, Styles P, Taylor DJ. Excessive intracellular acidosis of skeletal muscle on exercise in a patient with a postviral exhaustion/fatigue syndrome: a P 31 nuclear magnetic resonance study. lancet $198+;$; : 1367-9.

2 Brownstein MJ, Palkovits M. Kizer JS. Effect of surgical isolation of the hypothalamus on neurotransmitter content. Brain Res 1976;117:287-95.

13 Grosser BI. Serotonin: a reappraisal. F Clin Psychiatry 1987;48(suppl):3-4.

14 Kato Y, Nakai Y, Imura H, Chihara K, Ogo S. Effect of 5-hydroxytryptophan
5-HTP on plasma prolactin levels in man. 7 Clin Endocrinol Metub $197+38: 695-7$.

15 Gregory CA, Anderson IM, Cowen PJ. Metergoline abolishes the prolactin response to buspirone. Psychopharmacologv 1990;100:283-4.

16 Quattrone A, Tedeschi A, Aguglia V, Scopaccasa F, Direnzo GF, Annunziato L. Prolactin secretion in man: a useful tool to evaluate the activity of drugs on central 5-hydroxytryptaminergic neurones: studies with fenfluramine. Br.7 Pharmacol 1983;16:471-5.

17 Meltzer HY, Flemming R, Robertson A. The effect of buspirone on prolactin and growth hormone secretion in man. Arch Gen Psychiatry 1983;40: 1099-102.

18 Neuhauser H, Laakmann G, Knossalla A. Neuroendocrine effects of buspirone. 16th CINP congress. P'sychopharmacology 1988;96 ( suppl i:393.

19 Yatham LN. Barry S, Dinan TG. Serotonin receptors, buspirone, and premenstrual sundrome. Lancet 1989:i:1447-8.

20 American Psichiatric Association. Diagnostic and statistical manual of mental disorders, third edition, revised. Washington, DC: APA, 1987.

21 Hamilton M. A rating scale for depression. I Neurol Neurosurg Psychiatry 1960;23:56-62.

22 Holmes GP, Kaplan JE, Gantz NM, Komarroff AL, Schonberger LB, Strauss $\mathrm{SE}$, $e t$ al. Chronic fatigue syndrome: a working case definition. Ann Inter .Hed 1988;108:378-9.

23 Gold PW, Goodwin FK, Chourosos GP. Clinical and biochemical manifestations of depression. N Engl f Med 1988;319:413-20.

(Accepled 18 February 1992

\title{
Audit of public education campaign to encourage earlier detection of malignant melanoma
}

\author{
Rona M MacKie, D Hole
}

\section{Abstract}

Objectives-To evaluate a public campaign to encourage earlier referral and treatment of primary cutaneous malignant melanoma and thus reduce mortality related to melanoma.

Design-Production and distribution of educational material aimed at adults. Update information sent to general practitioners before campaign. Analysis of data on melanoma before and after campaign in June 1985

Setting - West of Scotland, population $2 \cdot 7$ million.

Main outcome measures-Total numbers of referrals per month to melanoma clinic, numbers of melanomas diagnosed, change in distribution of thickness, and mortality before and after introducing the campaign.

Results - Referrals to the pigmented lesion clinic increased by $278 \%$, from five a week in June-July 1984 to 19 a week in June-July 1985 . Twice as many women as men were referred to the clinic $(49 \%$ of referrals were of women aged under 65 ). The numbers of newly diagnosed primary cutaneous melanoma were 63 (12/month) in January-May 1985 and $146(21 /$ month $)$ in June-December 1985 , an increase of $131 \%$. The percentage of tumours detected that were less than $1.5 \mathrm{~mm}$ thick rose significantly by $16 \%$ (95\% confidence interval $11 \%$ to $19 \%$ ), from $38 \%$ (328) in $1979-84$ to $54 \%$ (592) in 1985-9. Mortality began to fall in women from 1988.

Conclusions-The public education campaign succeeded in reducing the absolute number of thick

Department of

Dermatology, University of Glasgow, Glasgow

G12 8QQ

Rona M MacKie, professor of dermatology

Cancer Surveillance Unit, Greater Glasgow Health

Board, Glasgow

D Hole, senior statistician

Correspondence to:

Professor MacKie.

BMJ 1992;304:1012-5 were in comparison with other countries there wer high proportion of patients in Scotland with thick primary tumours $(\geqslant 3.5 \mathrm{~mm}$ thick). As primary tumour thickness is well established as the most important prognostic factor a decision was made to introduce a public education campaign aimed at encouraging detection of melanomas when they were thinner and thus in time reducing mortality related to melanoma. Previous work had established that the main reason for delayed referral and thicker tumours seemed to be lack of public knowledge of the features of early melanoma rather than inappropriate advice or treatment by general practitioners or hospital induced delays in instituting appropriate treatment. ${ }^{2}$ We report the effects of a public education campaign aimed at early detection six years after its introduction.

\section{Methods}

PREPARATION FOR CAMPAIGN

Details of the organisation of the campaign have been published. ${ }^{3}$ It was decided to base the campaign on initial screening by family doctors and to provide for them a no waiting list rapid referral weekly specialist clinic for immediate assessment and biopsy or treatment as appropriate. A sample of 100 local general practitioners were asked to collaborate and to state what if any preparatory activities would be of value. Suggestions to the general practitioners included booklets on recognising early melanoma and related topics, videos for practice use, problem solving case histories tapes, and recorded telephone message. Eighty seven general practitioners indicated that they supported the proposal.

Most doctors expressed a wish for update material, mainly in the form of a booklet on melanoma. This was prepared, with comments and suggestions from 43 general practitioners. A companion booklet on benign melanocytic naevi, a set of 12 problem solving case histories, and a teaching video were also prepared. During the four months before the launch of the public education campaign this material was circulated to all Glasgow based general practitioners and to a high proportion of practitioners in adjacent health boards in the west of Scotland. In addition plans for the educational activity were widely publicised at general practitioners' study days, at hospital meetings, and at meetings organised specifically for nurses and other health care professionals.

The material for public education comprised colour 